\title{
高繰り返し電子ビーム励起KrFレーザー増幅器の開発
}

\author{
奥田 功 \\ (独) 産業技術総合研究所 (テ305-8568 茨城県つくば市梅園 1-1-1 中央第2)
}

\section{Development of a High-Repetition-Rate Electron-Beam-Pumped KrF Laser Amplifier}

\author{
Isao OKUDA
}

National Institute of Advanced Industrial Science and Technology (AIST), Tsukuba Central 2, 1-1-1, Umezono, Tsukuba, Ibaraki 305-8568

(Received October 20, 2003)

\begin{abstract}
A high-repetition-rate electron-beam-pumped $\mathrm{KrF}$ laser amplifier under development at AIST is described. The outline of the laser system developed for long-time operations under repetitive pumping conditions is introduced and test results measured at a repetition rate of $1 \mathrm{~Hz}$ are presented. The laser system and experimental results are evaluated in view of future laser drivers of inertial fusion energy.
\end{abstract}

Key Words: KrF laser, High repetition rate, Electron beam, Lifetime, Laser driver

1.はじめに

レーザー核融合用のエネルギードライバーを想定した 電子ビーム励起KrFレーザーの高繰り返し動作技術の開発 について述べる，KrFレーザーはガス媒質故に高繰り返し 動作において本質的な困難さが無く，内部効率が高いこ とに加えて，大面積電子ビームによって大容積レーザー ガスを高効率で励起することが可能であり，大口径化， 大出力化が容易である。更に燃料球へのエネルギー投入 に有利な紫外域の波長を有し，波長幅が広いことから レーザービーム強度分布の平滑化, 標的の一様照射が容 易である，等々，エネルギードライバーとしての能力を

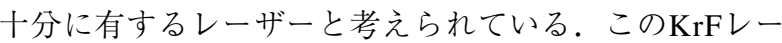
ザーの能力を引き出し，また照射実験に資するために， 当所ではこれまで口径 $60 \mathrm{~cm}$ のレーザーガス容器及び出力 空を有する電子ビーム励起KrFレーザー装置“Super ASHURA (Amp4)”の開発を行い，同レーザー増幅器から 約 $3 \mathrm{~kJ}$ のレーザー出力を得た1)。このレーザー装置の外観 をFig. 1 に示す。この大口径レーザー増幅器の開発におい て得られた成果を基に，実用炉用ドライバーで要求され る電子ビーム励起式 KrFレーザーの高繰り返し動作技術の 開発に着手した ${ }^{2)}$. 現在当所で開発を進めている高繰り返 し電子ビーム励起KrFレーザー装置をFig. 2に示す。

高繰り返し電子ビーム励起KrFレーザーの開発において は，従来の単発動作のレーザー装置では問題にならな かった様々な技術課題を解決する必要がある。すなわち 高電圧電源の高繰り返し化, 長寿命化, 電子ビーム発生 部及び光学素子の高耐力化等, 多くの課題があり, 各国 で電子ビーム励起KrFレーザーを用いて様々な研究開発が 進められている(米国NRL “Electra” (Fig. 3) 3)，ロシアP. N.
Lebedev Phys. Inst. “Garpun” $\left.{ }^{4)}\right)$. 当所では高繰り返し動作 の基本技術の開発を目標として, 特に高電圧パルス電 源, 及び電子ビーム発生部の長寿命化のための研究開発 を行っている。具体的には高電圧磁気スイッチをべース とした高電圧パルス回路を導入し，レーザー出力 $20 \mathrm{~J}$ 規模 の $1 \mathrm{~Hz}$ 動作のレーザー装置の開発を通して, 電子ビームエ ミッターの長寿命化, ダイオード真空部とレーザーガス を隔てる電子ビーム透過フォイルの冷却等に関して研究 開発を進めている。

\section{2. 高繰り返しパルスパワー}

電子ビーム励起KrFレーザー装置の高繰り返し動作のた めには，まずパルスパワーシステムの長寿命化が必要で あるが，そのために我々の装置では磁気スイッチをべー

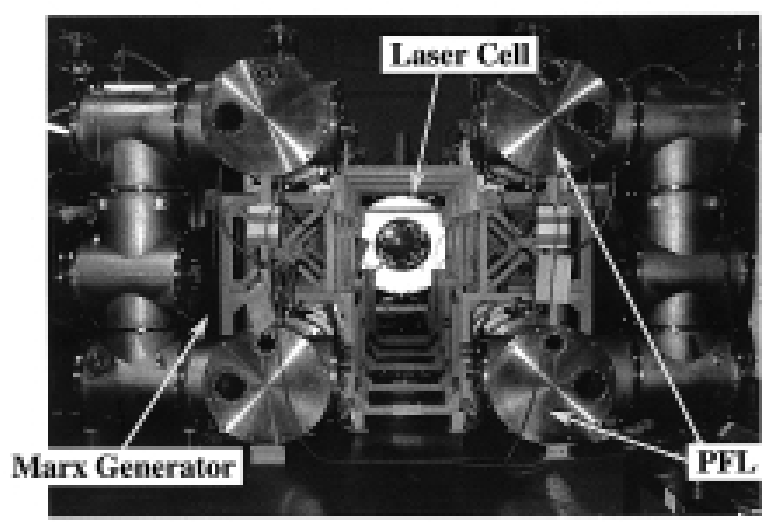

Fig. 1 60-cm-aperture electron-beam-pumped $\mathrm{KrF}$ laser, "ASHURA-Amp4". 


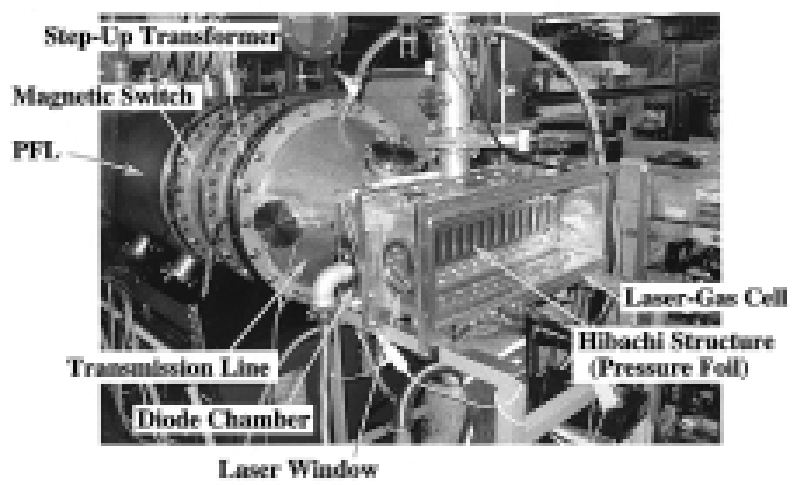

(a)

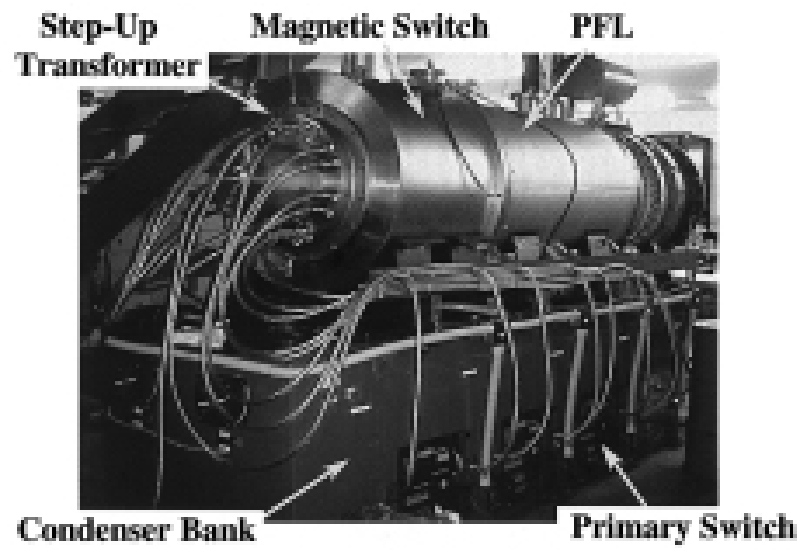

(b)

Fig. 2 High-repetition-rate electron-beam-pumped $\mathrm{KrF}$ laser under development at AIST. (a) Front view, (b) Rear view.

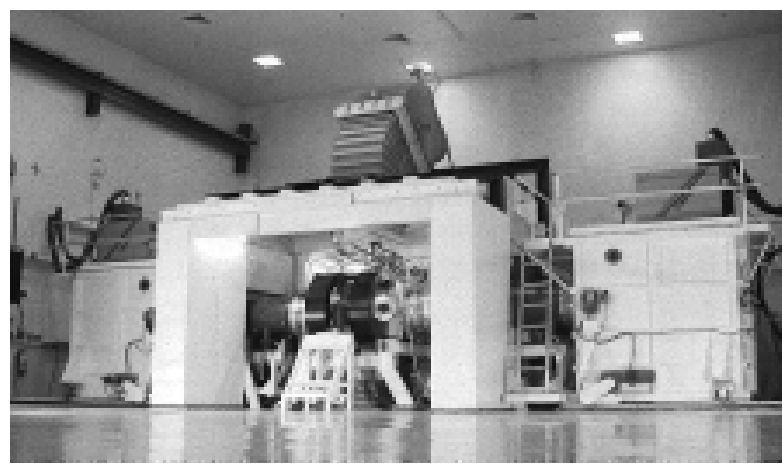

Fig. 3 High-repetition-rate electron-beam-pumped $\mathrm{KrF}$ laser "Electra" at NRL.
スとしたパルスパワー回路を整備した。パルスパワー回 路の構成をFig. 4に示す。これまで大出力レーザー用の高 電圧電源においては高電圧スイッチとしてスパーク ギャップが用いられてきたが，それらは特に長時間動作 においては電極の消耗が大きな問題となっていた。そこ で同高繰り返しレーザー装置の電源部ではスパーク ギャップを排し，長時間耐久性を有する磁気スイッチ及 び昇圧トランスをベースとしたパルスパワー回路を導入 した。同回路の動作としては，まず初段蓄積コンデン サー (8台並列, 各 $30 \mathrm{kV}$ 充電)に定常的にエネルギーを貯 え, 各並列充電回路の主放電スイッチ(サイラトロン), 昇 圧トランス $(1: 10)$ 及び1段の磁気圧縮回路を経て純水充 填のパルス成形線路 $(\mathrm{PFL})$ を充電する $(300 \mathrm{kV}, 0.2 \mu \mathrm{s})$. PFL充電完了後, その出力側の磁気スイッチが動作して 80 $\mathrm{ns}$ パルスが生成され，パルストランス $(1: 2)$, 同軸出力線 路，及び真空隔壁を通して $300 \mathrm{kV}$ パルスを電子ビーム発生 用ダイオードに伝搬する。なお磁気スイッチ及び昇圧卜 ランスの磁性体コアには, 比較的大きな磁束変化量 $(3.2$ T)を有し，エネルギー損失の少ない鉄系アモルファスを 用いている5 イッチを用いているが，固体スイッチ6)を用いることで電 源の一層の長寿命化が可能である.

同パルスパワー回路において，PFLのスイッチングに磁 気スイッチを用いることでPFLの充放電が1 Hz動作におい て長時間にわたり安定してなされている．PFL充電波形を Fig. 5に示す.この波形はPFL出力側の昇圧トランス $(1: 2)$ の直後に模擬負荷を設置し, PFL出力端 (水中)に置いた抵 抗分圧器で測定した。この試験結果から，定格通りの高

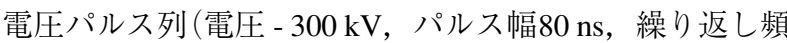

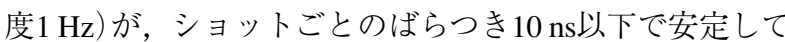
得られている7). PFLのスイッチングに磁気スイッチを用 いる場合，PFL充電中ダイオードにプレパルスが現れる が，出力線路に誘電率の大きい純水を充填し線路の容量 を大きくしているので，プレパルスの大きさは電子ビー ムを発生させないレベル $(<30 \mathrm{kV})$ に維持されるので問題 無い。必要に応じて出力線路の延長により更に容量を増 やすことも可能である。また電子ビームダイオードから の反射波が磁気スイッチに戻った際，磁気コア中の磁束 密度を減少させ磁気スイッチをオフにする恐れもある が，出力線路の長さをPFLと同じ長さまで延長し伝搬時間 を調整しているので問題無い.

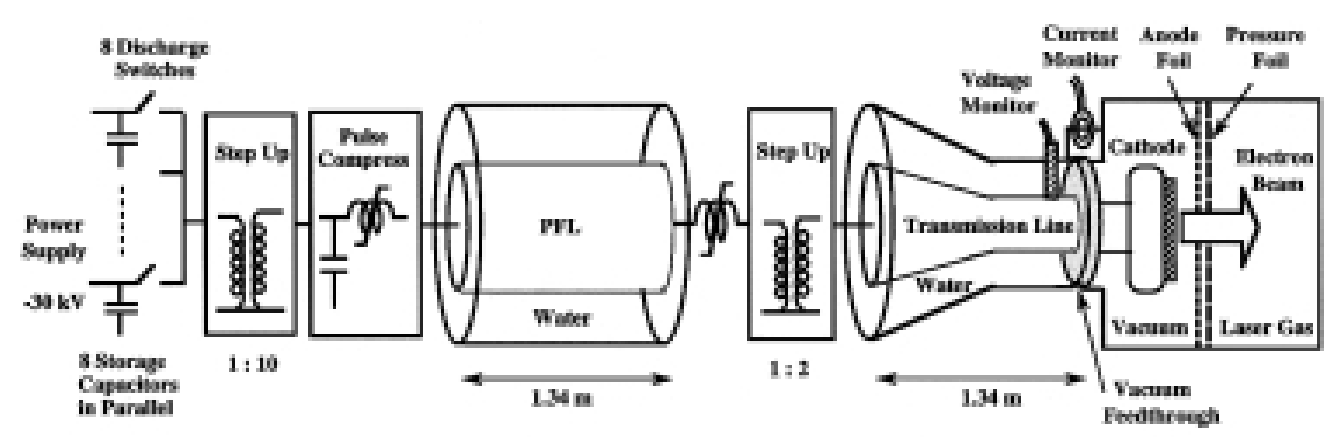

Fig. 4 Pulsed-power system of the high-repetition-rate electron-beam-pumped $\mathrm{KrF}$ laser. 


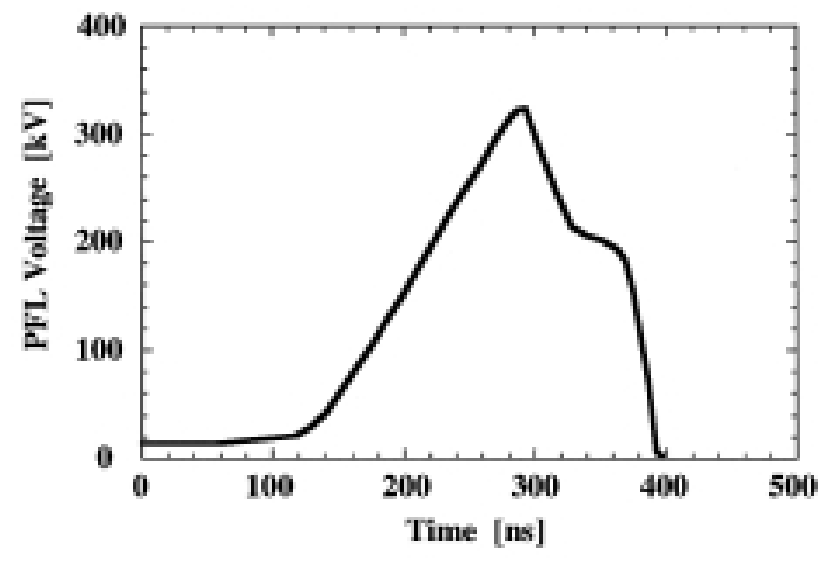

Fig. 5 Measured PFL waveform.

レーザー装置を大型化した場合においても磁気スイッ チをべースとした回路が有効であるが, 磁気圧縮では磁 気スイッチの飽和インダクタンス及びエネルギー損失を 考慮し，一般にパルス圧縮比を5程度としている．従って 本装置は小規模なのでPFL充電側において磁気圧縮回路を 1段としているが，装置を大型化した場合には多段の磁気 圧縮回路が必要となり，その結果エネルギー転送効率が 著しく低下する。しかし電子ビームダイオードに供給す るべきエネルギーを多数のPFLに分割し，また高速大電流 スイッチを用いることで, 縮小された各PFLの容量を初段 蓄積コンデンサーから直接充電することが可能である. この回路構成においては, 初段蓄積コンデンサーとPFLの 間を1段の昇圧トランスまたは線形誘導電圧重畳器(LIVA) のみによって接続することができる，LIVAを用いたPFL 充電回路の構成例をFig. 6に示す。この様なPFL充電回路 によって，初段蓄積コンデンサーから電子ビームダイ オードまで80\%以上の効率でエネルギーを転送すること が可能となり, その結果レーザー光出力まで5.5\%以上の レーザー装置の総合効率が可能と見積もられている ${ }^{8)}$.ま た初段スイッチに固体スイッチを用いることで更に長寿 命化も可能であり，この様な簡素化したパルスパワー回

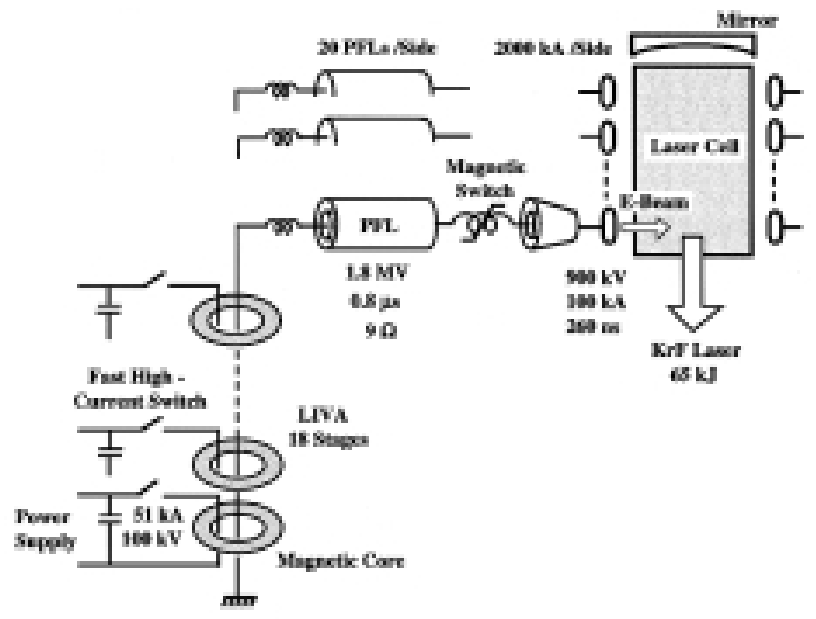

Fig. 6 Conceptual design of a high-efficiency pulsed power system using a linear induction voltage adder (LIVA) for a $65 \mathrm{~kJ} \mathrm{KrF}$ laser module of a multi-megajoule laser-driver system.
路を用いることにより，レーザードライバーに要求され る大エネルギー化, 高効率化, 高繰り返し化を同時に達 成できると期待される.

\section{3. 電子ビームダイオード及びHibachi構造}

電子ビーム励起KrFレーザー装置では，真空中に置かれ た大面積の平面陰極と陽極フォイルの間で電子ビームを 発生，加速させ，陽極フォイル及び圧力フォイル (真空部 とレーザーガスの隔膜) を通して大気圧程度のレーザーガ ス中に電子ビームを打ち込む。 ここで陽極フォイル及び 圧力フォイルを支持し，同時に電子ビーム透過口の役割 を果たす機構がHibachi構造と呼ばれるものである。電子 ビーム発生部 (ダイオード) 及びHibachi構造を Fig. 7に示 す。電子ビーム透過口 $\left(69 \times 11 \mathrm{~cm}^{2}\right)$ には，レーザーガス 圧に対して圧力フォイルを支持するために，幅 $0.8 \mathrm{~cm}$ のリ ブを $5 \mathrm{~cm}$ 間隔で配置している。ここで陽極フォイルにはチ タン $(10 \mu \mathrm{m}$ 厚), 圧力フォイルにはHavar(後述)を用いてお り，両フォイルの間はダイオード側に真空引きしてい る.このHibachiでは, 後述の様にフォイル支持用のリブ 中に冷却水を流せる構造としているが, 電子ビーム透過 口の開口率は既存装置と同程度 $(84 \%)$ であり, 電子ビー 厶の透過損失は小さい. なお㓌極表面の電界放出板 $(65 \times$ $\left.8 \mathrm{~cm}^{2}\right)$ には現在ベルベットを使用しており，陽極-陰極 $(\mathrm{A}$ $\mathrm{K})$ 間隔は $3 \mathrm{~cm}$, ダイオードインピーダンスは約 $7 \Omega$ として いる.

このダイオード及びHibachi構造を用いて得られたダイ オード電圧, 電流波形をFig. 8に示す. $1 \mathrm{~Hz}$ での連続動作 においてダイオード電圧, 電流波形は安定しており，パ ルスあたりの電子ビームエネルギーは580 Jが得られてい る。これまでに $1 \mathrm{~Hz}$ の繰り返し頻度で電子ビームパルスを 約1000ショット連続して発生させ，陽極フォイル及び圧 カフォイルを通してレーザーガス中に電子ビームを打ち 込んだ。この連続ショット数は, 初段放電スイッチの誤 動作に伴う運転シーケンスによって制限されたものであ る. ダイオードの真空度は $1 \mathrm{~Hz}$ 動作の開始時に $4.4 \times 10^{-6}$ Torrで, 約 90 ショット後に $1 \times 10^{-4}$ Torrに達し, 以降連続 動作の終了まで $1 \sim 2 \times 10^{-4}$ Torrの真空度を維持した9). ダ

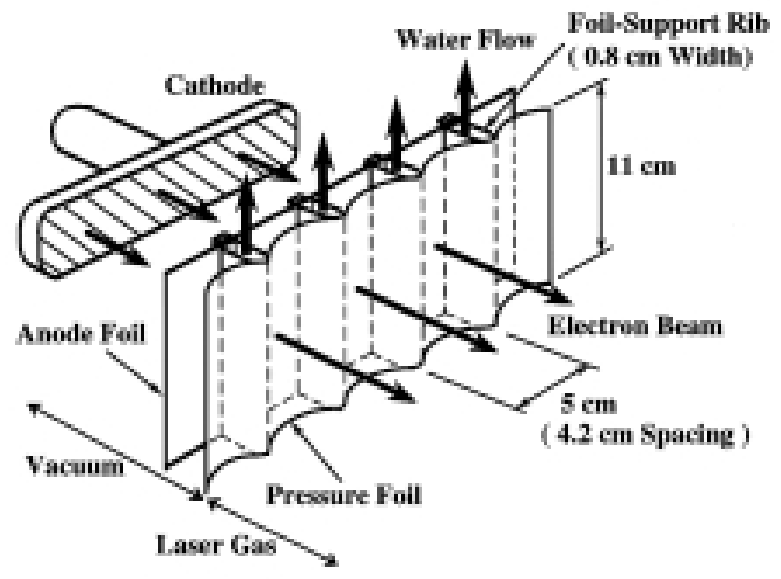

Fig. 7 Hibachi structure and electron-beam diode. 
(a)

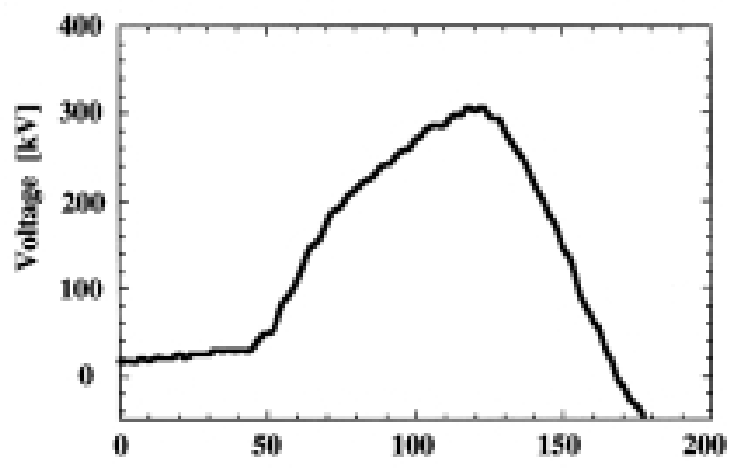

(b)

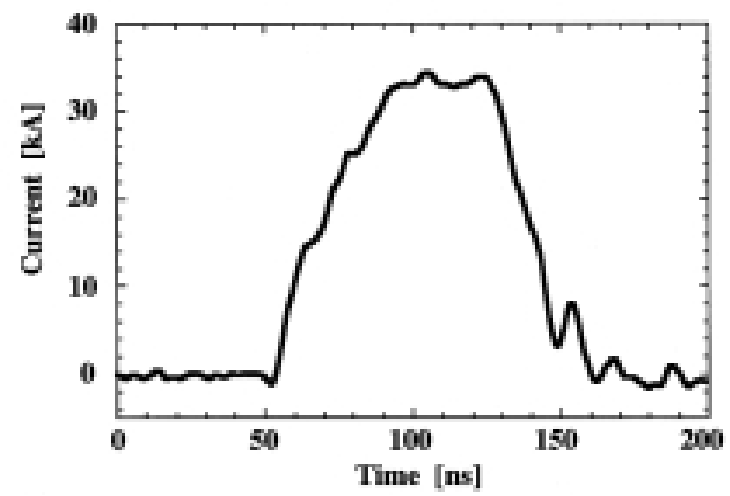

Fig. 8 Measured diode voltage (a) and current (b) waveforms.

イオード真空度の時間変化をFig. 9に示す。この連続運転 の終了時においても真空度は安定しており, ダイオード の真空に関しては1000ショット以上の連続 $1 \mathrm{~Hz}$ 動作が可能 であった. ダイオードの真空劣化は, 繰り返し頻度, 電 子ビームエネルギー，及び連続運転時間を制限すること になり，またA-K間の短絡，真空沿面の絶縁破壞をもたら す恐れもあるが，実験においてそのような問題は見られ ていない.なおこれまで同一の圧力フォイルにおいて， 合計約 8,000 ショットの電子ビームを得ている。この ショット数は初段放電スイッチの誤動作に起因したダイ オード電圧の不安定化 $(\mathrm{A}-\mathrm{K}$ 短絡による陽極及び圧力フォ イルの損傷)で決まっており，圧力フォイル自体はまだ寿 命に達していない.

電子ビームエミッターとしては, 現在ビームの一様性 を考慮してベルベットを使用しているが，今後の一層の 長時間運転に向けて高耐久性を有する電子ビームエミッ

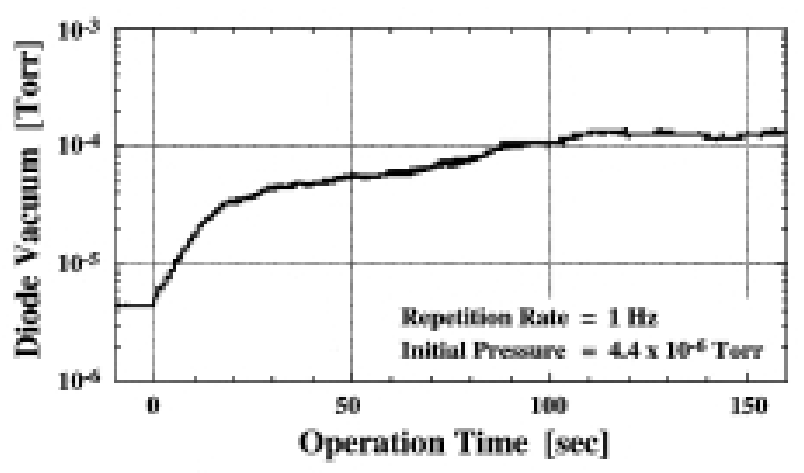

Fig. 9 Temporal evolution of the diode vacuum in a $1 \mathrm{~Hz}$ operation.
ターの開発が重要となる。高繰り返し動作実験と平行し てこれまでに様々なエミッターを試作し，その高耐力 化, 高性能化を進めてきた(鋸歯状電界放出エミッター, 高融点ナノ材料を用いたエミッター10), 高融点材料の表 面に微細加工を施したエミッター11), 誘電体表面の部分 放電を利用したエミッター，等)，特に誘電体をベースと したエミッターは既に長寿命が報告されており12)，また 低ガス放出が期待できるのでダイオード真空度の維持に も有効であろう。まだ最終的な長寿命エミッターの選択 には至っていないが, これまでの我々の経験を基に, 長 時間耐久性を有し，ビーム一様性に優れたエミッターの 実現は可能と考えられる。

\section{4. 圧カフォイルの温度管理}

高繰り返しレーザー装置では，電子ビームが陽極フォ イル及び圧力フォイルを通過する際，電子ビームエネル ギーの一部がフォイルに蓄積し，フォイルは繰り返し加 熱されることによって高温に達する。 その結果, 特に圧 カフォイルの張力低下によって，レーザー装置の運転時 間が制限される可能性がある。従って電子ビーム発生部 における今一つの重要な課題は, 圧力フォイルからの熱 の除去である. 同レーザー装置における圧力フォイルの 冷却は，レーザーガスの対流，熱放射と共に，フォイル 支持リブ中に流す冷却水への熱伝導によって行っている (Fig. 7). 圧力フォイルには高温においても大きな張力を 有し $(1410 \mathrm{MPa}, 800 \mathrm{~K})$ ，またフッ素に対する耐性に優れ たコバルト合金 $\left(\operatorname{Havar}^{13)}\right)$ を用いている。陽極フォイルに は現在チタンを用いているが, 高融点, 高熱伝導率を有 するモリブデン等の使用も想定される。このように大き な張力を有する合金の使用により，圧力フォイルの厚み を $12 \mu \mathrm{m}$ 程度まで薄くすることが可能である．密度の違い を考慮すると, この圧力フォイルの電子阻止能は $23 \mu \mathrm{m}$ 厚 程度のチタンに相当し, これは既存装置の場合と変わら ない.またこのHibachiでは陽極フォイルと圧力フォイル の間には冷却ガスを流さず, 前述の様に電子ビーム透過 口の開口率も大きいので, 電子ビーム透過率を既存の単 発動作のレーザー装置と同程度に維持しつつ圧力フォイ ルを冷却することが可能である。

フォイルの冷却性能の評価を目的として, 現在 $1 \mathrm{~Hz}$ 動作 の下で圧力フォイルの温度測定を進めている。実験では レーザーガスは循環させず，圧力フォイル正面のレー ザーガス容器壁に設置した $\mathrm{CaF}_{2}$ 空を通して, 赤外線カメ ラ (波長3 $5 \mu \mathrm{m}$ ) を用いて圧力フォイルの温度計測を行っ ている。測定結果を計算結果とともにFig. 10に示す ${ }^{14)}$. 横 軸は, 圧力フォイルに蓄積する電子ビームの平均蓄積パ ワー $P_{\mathrm{dep}}$ (単位面積, パルスあたりの電子ビーム蓄積エネ ルギーX繰り返し頻度)である． $P_{\mathrm{dep}}$ 值は電子ビームエネル ギーの測定值 (<360 J/パルス), 及び陽極フォイルの透過 率, 圧力フォイルの蓄積率の各計算值 $(94 \%, 13 \% / 250$ $\mathrm{kV})$ 7) を基に算出した。 ここでHibachi（フォイル支持リブ） の幾何学的透過損失 $(16 \%)$ は $P_{\mathrm{dep}}$ 值に影響しない. 圧力 フォイルの温度は水冷リブで囲まれた電子ビーム注入口 


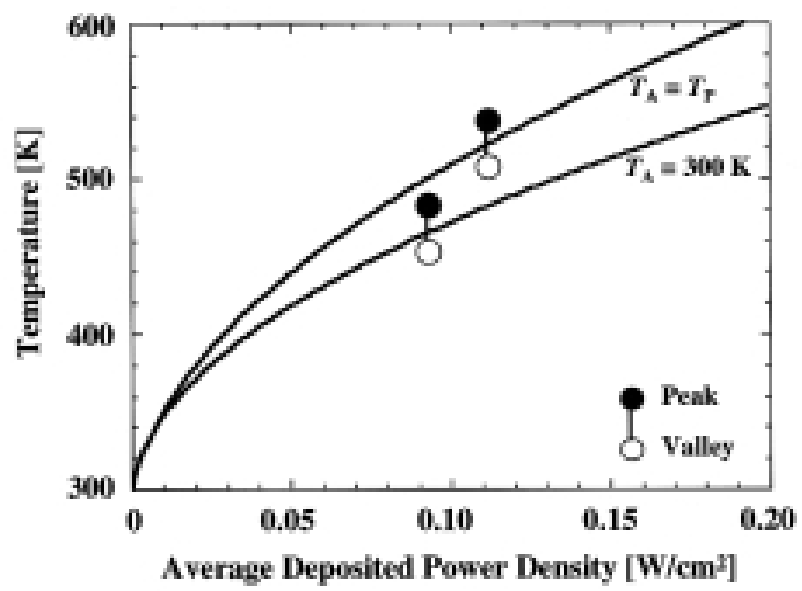

Fig. 10 Pressure-foil temperature $\left(T_{\mathrm{p}}\right)$ as a function of average deposited electron-beam power density in the pressure foil $\left(P_{\mathrm{dep}}\right)$. Measured peak and valley temperatures are shown as solid dots and open circles, respectively. Calculated lines are for two anode-foil temperatures assumed $\left(T_{\mathrm{a}}\right):$ 1) $T_{\mathrm{a}}=300 \mathrm{~K}$, 2) $T_{\mathrm{a}}=$ $T_{\mathrm{p}}$.

$\left(4.2 \times 11 \mathrm{~cm}^{2}\right)$ の中央において最大となり, $1 \mathrm{~Hz}$ の電子ビー ム打ち込みに伴って1秒間隔のパルス列として観測される が，Fig. 10の測定值はその温度変動の上限と下限を示して いる. 圧力フォイルの温度計算はフォイル周囲の温度, 放射率, 形状等を全て考慮する必要があり複雑である が，ここでは電子ビーム注入口の中心部のみについて定 常状態を仮定して行った7). 圧力フォイルの冷却機構は レーザーガス中での自然対流 (アルゴン 1 気圧), 及び圧力 フォイル両面からの熱放射 (フォイル放射率 $=0.2$ ) とし た。圧力フォイルは熱伝導率が小さく $(13 \mathrm{~W} / \mathrm{mK})$, 水冷リ ブの間隔が大きいので $(5 \mathrm{~cm})$, 注入口中心部では熱伝導を 無視した．陽極フォイルの温度は，1) 室温の場合 $(300 \mathrm{~K})$ と, 2) 圧力フォイルと等しい場合 (陽極フォイル，圧力 フォイル間の放射熱交換を無視した場合)の2通りの温度 を仮定した．実験の測定範囲 $\left(P_{\mathrm{dep}}<0.11 \mathrm{~W} / \mathrm{cm}^{2}\right)$ では, 測 定結果は計算結果でほぼ説明されている。圧力フォイル の張力を考慮し, フォイルの許容温度を $800 \mathrm{~K}$ 程度 ${ }^{13)}$ と仮 定しているが, 測定されたフォイル温度はこの範囲に十 分収まっている. 現在, 平均蓄積パワーを $P_{\mathrm{dep}}=0.15$ $\mathrm{W} / \mathrm{cm}^{2}$ 程度まで増加させて実験を続けているが, 張力低下 に起因するフォイルの損傷は見られていない.

現在の実験条件 $\left(P_{\mathrm{dep}}=0.1 \sim 0.2 \mathrm{~W} / \mathrm{cm}^{2}\right)$ において, 電子 ビーム注入口の中心部における圧力フォイルの冷却機構 は, フォイル両面からの熱放射とレーザーガス中の自然 対流がともに50\%程度と計算から見積もられる. 他方, 将来のレーザードライバーを想定しレーザー装置を更に 高繰り返し化, 大出力化した場合には, レーザーガスを 循環し強制対流によって圧力フォイルの冷却を行う。こ のようにレーザーガス中の対流冷却を増強した条件にお いても，既に圧力フォイルの冷却試験が開始されてい る15). 現在我々のレーザー装置では, 自然対流の条件下 (フォイル温度 $500 〜 700 \mathrm{~K}$ ) において1〜2 Hzの繰り返し頻 度で動作試験を行い, 圧力フォイル，フォイル支持機
構，及びレーザー装置全体の耐久性の評価を続けてい る.

\section{5. 高繰り返しレーザーガス励起}

以上の結果を基にして行ったレーザーガスの高繰り返 し励起試験の結果を示す。この実験ではHibachi構造を通 して，レーザーガス中 (1200 Torr)に $1 \mathrm{~Hz}$ の繰り返し頻度 で電子ビームの打ち込みを行った。測定したレーザーガ ス圧力の時間変化をFig. 11に示す. この結果から, 電子 ビームエネルギーが $1 \mathrm{~Hz}$ の繰り返し頻度でレーザーガス中 に連続的に蓄積していることがわかる. ガス中への蓄積 エネルギーはFig. 11に見られる圧力パルス列のそれぞれの 波高から，パルスあたり $280 \mathrm{~J}$ と計算される(初段蓄積 2 $\mathrm{kJ}$, 電子ビーム $580 \mathrm{~J})$. $1 \mathrm{~Hz}$ 動作における飽和レーザー増 幅は未着手であるが, 既に60 cm 口径の電子ビーム励起 $\mathrm{KrF}$ レーザーにおける飽和増幅実験において，レーザーガ ス中の蓄積エネルギーの $9 \%$ (内部効率)をレーザー光とし て取り出せることが確認されている16). 従ってFig. 11の結 果は, レーザー空の口径 $(13 \mathrm{~cm})$ をガス容器断面積 $(19 \times 29$ $\left.\mathrm{cm}^{2}\right)$ に等しくし飽和増幅を行った場合，パルスあたり $25 \mathrm{~J}$ のレーザーエネルギーを $1 \mathrm{~Hz}$ の繰り返し頻度で連続的に取 り出したことに相当する17).

\section{6. まとめ}

現在進められている高繰り返し電子ビーム励起KrFレー ザーの開発状況について述べた。パルスパワーに関して は磁気スイッチをべースとした回路で高耐力化が可能で あり，初段スイッチに固体スイッチを用いることで一層 の長寿命化も見込まれる. また高速大電流スイッチ及び 多数のPFLを用いた回路構成により，初段蓄積コンデン サーから電子ビームダイオードに至るまで, 高効率でエ ネルギーを転送することが可能である。電子ビームエ ミッターに関しても現在続けられている電子放出板の高 耐力化, 高性能化により, 高繰り返しレーザー用の長寿 命エミッターの実現が可能であろう. 圧力フォイルの温 度管理に関しては, 将来のレーザードライバーで想定さ

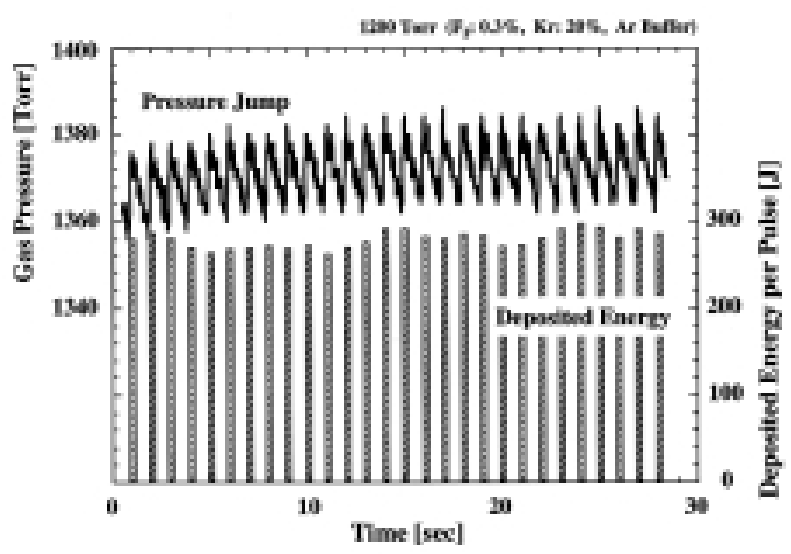

Fig. 11 Measured pressure jumps and deposited electronbeam energy per pulse in the laser gas. 
れるフォイル温度領域において動作試験が行われてお り，更に繰り返し頻度及び電子ビームパワーを増大して 耐久性の確認がなされつつある。 以上の成果を基にレー ザードライバーで要求される大エネルギー, 長寿命, 高

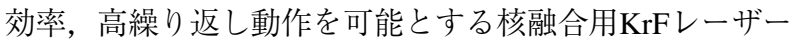
の基礎技術が確立されるものと考えられる. その他光学 空の高耐力化等, レーザーシステム全体の長寿命化を図 る必要があるが, 現在行われている各種耐久性試験を通 して，エネルギードライバーとしての KrFレーザー装置の 信頼性が確認されるものと期待される.

\section{謝 辞}

レーザー装置の写真提供に対して, 米国NRLのF. Hegeler氏に感謝する. 本研究は, 原子力委員会の評価に 基づき, 文部科学省原子力試験研究費により実施された ものである。

\section{参考文献}

1) I. Okuda, E. Takahashi, I. Matsushima, Y. Matsumoto, H. Yashiro, E. Miura, T. Tomie, and Y. Owadano: Fusion Engineering and Design 44 (1999) 377.

2) I. Okuda, E. Takahashi, I. Matsushima, Y. Matsumoto, S. Kato, and Y. Owadano: Jpn. J. Appl. Phys. 40 (2001) 1152.

3) J. D. Sethian, M. Friedman, J. L. Giuliani, R. H. Lehmberg, M. Myers, S. P. Obenschain, P. Kepple, F. Hegeler, M. F. Wolford, S. B. Swanekamp, D. Weidenheimer, D. Welch, and D. V. Rose: Third Int. Conf. on Inertial Fusion Sciences and Applications, Monterey CA, Sep 7-12, 2003. Paper ThF1. 3. To be published in Fusion Sci- ence and Technology.

4) V. D. Zvorykin, S. V. Arlantsev, V. G. Bakaev, E. V. Polyakov, P. B. Sergeev, G. V. Sychugov, and D. A. Zayarnyi: Third Int. Conf. on Inertial Fusion Sciences and Applications, Monterey CA, Sep 712, 2003. Paper Tu11.2. To be published in Fusion Science and Technology.

5) C. H. Smith: IEEE Conf. Rec. of the 1988 Eighteenth Power Modulator Symp. (1988) p.336.

6) S. Schneider and T. F. Podlesak: Digest of Tech. Papers, 12th IEEE Int. Pulsed Power Conf. (1999) p.214.

7) E. Takahashi, I. Okuda, Y. Matsumoto, I. Matsushima, S. Kato, K. Kuwahara, and Y. Owadano: Proc. SPIE 3886 (2000) p.391.

8) I. Okuda, E. Takahashi, and Y. Owadano: Appl. Phys. B 71 (2000) 247.

9) I. Okuda, J. Ma, E. Takahashi, I. Matsushima, Y. Matsumoto, S. Kato, and Y. Owadano: Appl. Phys. B 72 (2001) 623.

10) I. Okuda, E. Takahashi, and Y. Owadano: Jpn. J. Appl. Phys. 40 (2001) 5407.

11) I. Okuda, E. Takahashi, and Y. Owadano: Jpn. J. Appl. Phys. 40 (2001) 7168

12) N. M. Bykov, V. P. Gubanov, A. V. Gunin, S. D. Korovin, O. P. Kutenkov, V. F. Landl, S. D. Polevin, V. V. Rostov, G. A. Mesyats, and F. Ya. Zagulov: Digest of Tech. Papers, 10th IEEE Int. Pulsed Power Conf. (1995) p. 71.

13) Technical Data Sheet of Hamilton Precision Metals, Inc.

14）奥田 功, G. Huailin, 高橋 栄一, 松嶋 功, 松本 裕治, 加藤 進, 大和田野芳郎：第49回応用物理学関係連合講演会講演予 稿集 (2002) 28a-ZE-12.

15) F. Hegeler, M. C. Myers, J. D. Sethian, M. Friedman, M. F. Wolford, S. B. Swanekamp, D. V. Rose, and D. Welch: Third Int. Conf. on Inertial Fusion Sciences and Applications, Monterey CA, Sep 7-12, 2003. Paper TuPo1.31. To be published in Fusion Science and Technology.

16) I. Okuda, E. Takahashi, and Y. Owadano: Appl. Phys. B 72 (2001) 897.

17）奥田功, W. Jin, 高橋栄一, 松嶋 功, 松本 裕治, 大和田野 芳郎：第50回応用物理学関係連合講演会講演予稿集 (2003) 28p-YR-2. 